\title{
The value of a name
}

Received: 2nd July, 2002

\section{Arthur Middleton Hughes}

is Vice-President for Business Development of CSC Advanced Database Solutions in Schaumburg, IL. He has spent the last 18 years designing and maintaining marketing databases for clients including telephone companies, banks, pharmaceuticals, packaged goods, software and computer manufactures, resorts, hotels and automobiles. He is the author of 'The complete database marketer' (McGraw Hill 1996), and 'Strategic database marketing' (McGraw Hill 2000)

\begin{abstract}
Most consumer names, addresses and e-mails have value in direct marketing. Some names are worthless, particularly those of packaged goods purchasers. Other names, particularly names with e-mails and permission to use them, can be highly valuable. This paper describes the methods whereby companies can compute the market value of a customer name and address. The value is based on the use that can be made of the name for such purposes as retention building, product promotion, viral marketing, list rental and many others.
\end{abstract}

The names and addresses of some ultimate consumers have always been valuable in direct marketing, if the marketer knows how to use them. Not all names are valuable however. Since the 1980s it has been discovered that names and addresses of purchasers of packaged goods sold in retail stores have almost no value. This was because it was not possible to market profitably to people using direct mail to get them to buy packaged goods in retail stores.

What could be done with a clean, householded database of all the families in America that use Ivory Soap? A lot of money could be lost. Database marketing is incremental. Ivory Soap is already selling in retail stores. The assumption might be that by sending direct mail messages, it might be possible to sell a little bit more, perhaps 10 per cent more of Ivory or another product from the same organisation, by communicating with potential customers. When the cost of direct mail is taken into account it is soon clear that the assumption is completely wrong. Ivory Soap is selling in some US supermarkets at US $\$ 1.29$ for four bars. The profit on those four bars is obviously tiny. A 10 per cent increase would be even more tiny. A good response to direct mail is 2 per cent. There is no way that direct mail could possibly increase sales sufficiently to pay for itself when promoting most packaged goods.

This is true not only for Ivory Soap but for almost everything sold in a supermarket, office supply store, hardware store or department store. Manufacturer after manufacturer have tried promotions with rebates by direct mail. They collected thousands of consumer names and addresses in this way. None of them figured out a way to make money from those names.

That does not mean that consumer names are worthless for direct mail. Catalogues obviously work extremely well. Supermarkets profitably send circulars getting customers to come back, or to shop on Tuesday night. Names of parents of new babies are very valuable indeed. What does not work well is the 
two-step direct mail process for ordinary packaged goods: it is better to send consumers a direct mail letter inviting them to go to a retail store to buy the product. This can be done by television, radio or print - it works extremely well.

Why are packaged goods names worthless? There are several reasons:

- low margins

- slow certificate redemption, it takes up to six months to find out what is happening

- to make a profit, repeat sales (low margin) are essential. It is not possible to redeem a certificate for every sale without going broke, so the market never finds out about the subsequent sales

- there is no way to work out if the strategy is succeeding. When people buy packaged goods at a retail store their purchase may be captured by the store when the product is scanned. If the store has a proprietary card, they may know that a particular customer bought a tube of Crest toothpaste on 17th August. They will not, however, tell Crest about it because of privacy. The small amount that Crest might pay for the information would not compensate for the bad public relations if the customer found out their name was being used and complained about it publicly. Retail stores simply will not sell this information - they have been burned, and know better

- Crest would not want the information, anyway, because they cannot work out how to use it to make a profit.

\section{THE PHONE CALL}

A year after the dot.com crash, the author had a telephone call from the
Table 1: Chicago homebuyers

\begin{tabular}{ll}
\hline & Amounts \\
\hline Names & 500 \\
Home value & $\$ 300,00$ \\
Commission rate & $6 \%$ \\
Commission revenue & $\$ 9,000,000$ \\
Success rate & $5 \%$ \\
Net profit & $\$ 450,000$ \\
Name value & $\$ 900$ \\
Name offering price & $\$ 450$ \\
\hline
\end{tabular}

chief executive (CEO) of a dot.com startup (they were still starting them up, despite the carnage). He told the author that his new venture would generate thousands of satisfied Web consumers who would gladly provide permission for resale of their contact information. He asked the author what the value of these names would be, so he could plug this number into the business plan required by his investors. He called the author because he had been told that the author had written several books and articles on the subject and could probably provide the answers he sought, over the phone.

The question had the author stammering. The author had never thought about the value of a name in the abstract like this. There are many facts to be pinned down before the value can be determined. In the first place, the questions are, 'Of value to whom? What are these names, and who would want to buy them? What can these names do for a potential buyer?' The CEO did not have these answers, but assumed that the author did.

So the author started to examine the question in detail. He began by visualising an ideal situation. Suppose a market had the names of 500 Boeing executives earning $\$ 100,000$ or more, who have to relocate from Seattle to Chicago within the next 60 days. What is the value of these names? To a large real estate chain in Chicago, these names could be very valuable indeed. 
Table 2: $C D$ buyers

\begin{tabular}{llll}
\hline & Year $\mathbf{1}$ & Year 2 & Year 3 \\
\hline $\begin{array}{llll}\text { Retention rate } \\
\text { Customers }\end{array}$ & $40 \%$ & $50 \%$ & $60 \%$ \\
$\begin{array}{l}\text { Average sale } \\
\text { Sales/Year }\end{array}$ & 200,000 & 80,000 & 40,000 \\
Revenue & $\$ 20.00$ & $\$ 30.00$ & $\$ 40.00$ \\
& 3 & 4 & 5 \\
Cost \% & $\$ 12,000,000$ & $\$ 9,600,000$ & $\$ 8,000,000$ \\
Costs & $80 \%$ & $75 \%$ & $70 \%$ \\
Market $\$ 10$ & $\$ 9,600,000$ & $\$ 7,200,000$ & $\$ 5,600,000$ \\
Total cost & $\$ 2,000,000$ & $\$ 800,000$ & $\$ 400,000$ \\
& $\$ 11,600,000$ & $\$ 8,000,000$ & $\$ 6,000,000$ \\
Profit & $\$ 400,000$ & $\$ 1,600,000$ & $\$ 2,000,000$ \\
Discount rate & 1 & 1.08 & 1.16 \\
NPV profit & $\$ 400,000$ & $\$ 1,485,608$ & $\$ 1,724,243$ \\
Cum profit & $\$ 400,000$ & $\$ 1,885,608$ & $\$ 3,609,852$ \\
Lifetime value & $\$ 2.00$ & $\$ 9.43$ & $\$ 18.05$ \\
\hline
\end{tabular}

Assuming that the Chicago real estate chain could sell homes to 5 per cent of these executives (a not unreasonable assumption), then each of the 500 names is worth $\$ 900$. The Chicago chain might be induced to offer as much as $\$ 450$ per name, and still make $\$ 450$. But this is assuming that the names can be sold only to a real estate dealer. The executives will be buying many new services in Chicago when they move, including:

- moving services

- doctor and dentist

- bank and insurance

— automobile and furniture.

These names are valuable to many different businesses. Their value certainly exceeds $\$ 450$ when all these potential buyers are factored in. Clever and aggressive marketing could yield a substantial profit from selling the names.

Is such a list of names of moving executives unique to the Boeing situation? Not at all. Companies shift their executives around all the time. But the dot.com CEO's list of names was not of high-income executives. It was of young people between 15 and 35 who purchased music over the Web. What would be the value of these names? This is a different proposition altogether, who would want to buy these names? The Chicago buyers already listed would probably be uninterested. Perhaps the names could be sold to other e-commerce sites. Amazon or CDNow might buy them. Some retailer or cataloguer might want them. Here the value would be much lower. How could the marketer go about calculating the value of a rented name?

The lifetime value of the acquired customers is a starting point. Table 2 computes the lifetime value to a retailer selling music CDs where the average sale is $\$ 20.00$.

What Table 2 shows is that the average newly acquired customer of the dot.com company is worth $\$ 18$ in the third year. The retention rate of customers tends to go up after the first year, as does the average order size. Of the 200,000 customers who might make a purchase, the average person might buy three times a year. Forty per cent of them would still be customers in Year 2 making four larger purchases per year. Fifty per cent of those would last to a third year buying even more.

The costs of servicing customers typically tend to go down each year as shown here. The discount rate is needed 
Table 3: Sales by media

\begin{tabular}{lllclll}
\hline & Budget \$ & Reached & CPM \$ & $\begin{array}{l}\text { Sales } \\
\text { rate } \%\end{array}$ & Sales & Cost/Sale \$ \\
\hline Television & 400,000 & $74,074,074$ & 5.40 & 0.04 & 29,630 & 13.50 \\
Radio & 400,000 & $71,428,571$ & 5.60 & 0.03 & 21,429 & 18.67 \\
Print & 400,000 & $25,000,000$ & 16.00 & 0.07 & 17,500 & 22.86 \\
Direct mail & 400,000 & $1,086,957$ & 368.00 & 1.80 & 19,565 & 20.44 \\
\hline
\end{tabular}

Table 4: Two methods of contact

\begin{tabular}{lll}
\hline & Direct mail & E-mail \\
\hline Names & 200,000 & 200,000 \\
Cost of message & $\$ 0.37$ & $\$ 0.04$ \\
Sending cost & $\$ 74,000$ & $\$ 8,000$ \\
Response rate & $1.8 \%$ & $1.0 \%$ \\
Responses & 3,600 & 2,000 \\
Customer lifetime value & $\$ 18.05$ & $\$ 18.05$ \\
Value of customers acquired & $\$ 64,977$ & $\$ 36,099$ \\
Less sending cost & $(\$ 9,023)$ & $\$ 28,099$ \\
Prospect lifetime value & $(\$ 0.05)$ & $\$ 0.14$ \\
Offering price & 0 & $\$ 0.07$ \\
\hline
\end{tabular}

to convert future profits into Net Present Value (NPV) profit so that these profits can be added together to get the cumulative profit. The lifetime value is determined by dividing the cumulative NPV profit by the original 200,000 customers to determine the value of a newly acquired customer. In this case, the newly acquired customers are worth $\$ 18$ in the third year. This is the value to a company selling CDs that has already acquired these customers.

So, to the dot.com the names are worth $\$ 18$. What would they be worth to a potential buyer? Let it be assumed that the potential buyer is selling a product of similar value, so their customer lifetime value once they had acquired the customers would be identical - $\$ 18$. What is the value of these names to a new company which wants to sell products to these customers?

An outside buyer, renting the name from the original company, has to consider the costs of acquiring these customers directly. There are two methods the outside buyer could use: direct mail or e-mail. Both possibilities are considered (see Table 4).

Using direct mail with a 1.8 per cent response rate, any direct mail offer would lose money. This is the proof of the assertion that database marketing does not work with packaged goods. With the database marketing by e-mail, however, profitable marketing becomes a possibility. The response rate will be lower, at 1 per cent, but the marketing costs are far lower. The value of a prospect name is 12 cents. The outside buyer might be willing to offer half of that for a name.

The lifetime value sets an upper bound for the offering price. Anyone who offers to pay the full lifetime value (LTV) for a prospect name would never make a profit. As a rule of thumb, it can be assumed that buyers will never offer more than half the prospect lifetime value to acquire a name. So the offering price of a name with a prospect LTV of $\$ 0.14$ could not be higher than $\$ 0.07$. 
Table 5: Value of a name

\begin{tabular}{ll}
\hline & Amounts \\
\hline Offering price & $\$ 0.07$ \\
Marketing costs & $25 \%$ \\
Net revenue & $\$ 0.053$ \\
Sales per year & 3 \\
Value of a name & $\$ 0.158$ \\
\hline
\end{tabular}

So, if the offering price of a prospect name to an e-commerce consumer name buyer is $\$ 0.07$ what is the name worth to the seller? Here marketing costs have to be considered. Buyers do not materialise from nowhere once names are acquired. To get names sold, most companies need the services of list managers and brokers who must advertise and get fees. The list owner will be lucky to get 75 per cent of the offering price from any one buyer. With luck, the names can be sold several times per year. So the value of a name looks something like the value shown in Table 5.

So there is an answer for the CEO of the new dot.com. The names are worth $\$ 0.16$ each if the CEO finds a good list manager, promotes the names and everything goes well.

As can be seen, this type of analysis is not difficult to do. It should be done before any business is created. If it had been done by the thousands of dot.coms set up before the crash, there might not have been the dot.com wipeout and the stock market crash. It is to be hoped some sharp pencil accounting will be seen in the future when 'cool ideas' are floated to venture capitalists.

\section{HOW TO COMPUTE LIFETIME VALUE.}

The lifetime value chart shown in Table 2 is typical of standard lifetime value charts. It has many uses. It can be used, for example, to determine:
- how much to spend on acquisition of customers

- how much to spend on retention programmes

- how much to spend on referral programmes

- the payoff from particular marketing strategies

- the rental value of a name

- the value of a company, based on its acquired customer base

- which group of customers should be retained, acquired or discarded.

The value of a name in a

business-to-business setting is now determined. It is assumed that there is a company that sells chemicals to industrial users, the company is called WardChem. The company has about 45,000 customers who spend from $\$ 5,000$ to $\$ 500,000$ per year on chemicals. The average order is $\$ 2,500$, and the average customer buys from WardChem eight times a year. Later these customers will be broken down into segments (low volume, medium, high volume, etc.), but for now, they will be lumped together into a single lifetime value table, so that the principles involved can be understood.

It is assumed that customers are newly acquired in Year 1 and their performance is examined over the next three years.

- the retention rate is the percentage of customers that last from year to year. As can be seen, WardChem loses 30 per cent of its newly acquired customers after the first year. It does better in subsequent years, rising to 80 per cent retention in the third year

- retained customers are those same customers in their first, second and third years with WardChem. New customers who arrive in Year 2 or Year 3 are not shown here. For them, 
Table 6: Lifetime value for WardChem

\begin{tabular}{llll}
\hline & Year $\mathbf{1}$ & Year 2 & Year 3 \\
\hline Retention rate & $70 \%$ & $75 \%$ & $80 \%$ \\
Retained customers & 45,000 & 31,500 & 23,625 \\
Average order & $\$ 2,500$ & $\$ 2,700$ & $\$ 2,900$ \\
Orders per year & 8 & 9 & 10 \\
Total revenue & $\$ 900,000,000$ & $\$ 765,450,000$ & $\$ 685,125,000$ \\
Cost percent & $75 \%$ & $71 \%$ & $69 \%$ \\
Variable costs & $\$ 675,000,000$ & $\$ 543,469,500$ & $\$ 472,736,250$ \\
Acquisition cost $(\$ 1,400)$ & $\$ 63,000,000$ & 0 & 0 \\
Retention costs $(\$ 90)$ & $\$ 4,050,000$ & $\$ 2,835,000$ & $\$ 2,126,250$ \\
Total costs & $\$ 742,050,000$ & $\$ 546,304,500$ & $\$ 474,862,500$ \\
& & & $\$ 210,262,500$ \\
Gross profit & $\$ 157,950,000$ & $\$ 219,145,500$ & 1.17 \\
Discount rate & 1.01 & 1.09 & $\$ 179,159,636$ \\
Net present value profit & $\$ 155,779,959$ & $\$ 200,894,344$ & $\$ 535,833,940$ \\
Cumulative NPV profit & $\$ 155,779,959$ & $\$ 356,674,303$ & $\$ 11,907$ \\
Lifetime value & $\$ 3,462$ & $\$ 7,926$ & \\
\hline
\end{tabular}

this is their Year 1. It is assumed that WardChem retains a base of about 45,000 customers. They do this by losing 9,000 and gaining 9,000 new ones every year. It is the history of the retained customers that is under study here:

- the average order size tends to grow every year. This is typical of all corporations

- the number of orders per year also tends to grow

- the cost percent is a rough number that estimates the average percentage of the selling price of company products that goes into the expense of manufacturing or distribution and other costs. The balance is profit or marketing costs

- the acquisition cost is computed by adding together all the expenses involved in one year in acquiring new customers: advertising on television, radio, print and direct mail; sales force salaries, commissions and bonuses and dividing that total by the number of customers actually acquired during that year

- the retention costs are those costs spent to keep customers happy and buying. It could cover an annual retreat, customer communications or customer services

- the discount rate is used to compute the net present value of profits received. Money that will arrive in one year or two years is obviously not as valuable today as money that arrives today. The discount rate is a number that puts all these amounts on the same basis so that they can be added together. There is a neat formula for the discount rate. It is $\mathrm{D}=\left(1+i^{\star} \mathrm{rf}\right)^{\text {waiting time }}$. In this formula for the calculation of the discount rate: $\mathrm{i}$ is the interest rate that the company pays for money; $\mathrm{rf}$ is the risk factor (the risk that the money will not materialise at all); the waiting time is the length of time the company has to wait until the money arrives. With consumers, this is usually 0 for the first year, and one year for the second year, etc. With business-to-business the picture is different. Most business-to-business customers pay in 30, 60 or 90 days. So the waiting time is determined 
Table 7: Discount rate calculation

\begin{tabular}{llll}
\hline & Year 1 & Year 2 & Year 3 \\
\hline Years to wait & 0 & 1 & 2 \\
Interest rate & $6.80 \%$ & $6.80 \%$ & $6.80 \%$ \\
Risk factor & 1.1 & 1.1 & 1.1 \\
Accts. rec. days & 70 & 75 & 80 \\
Discount rate & 1.01 & 1.09 & 1.17 \\
\hline
\end{tabular}

by adding these periods to the years. Table 7 is a simple chart used for calculating the discount rate of a business-to-business situation:

- the net present value (NPV) of profits is the gross profits divided by the discount rate

- the cumulative NPV profits is calculated by adding the profits from previous years to this year's profits

- the customer lifetime value is calculated by dividing the cumulative NPV profits in each year by the same number, in this case 45,000 (the total number of newly acquired customers). In this case, it shows that newly acquired customers are worth $\$ 9,123$ in their third year with WardChem.

\section{CALCULATING LTV BY SEGMENTS}

Calculating LTV for customers as a whole is useful. Even more useful is to calculate the LTV of segments. An automobile company may find that calculating the LTV of various models may be quite different. Two factors, in general, are responsible for the difference:

- the profit per car to the manufacturer - the repurchase rate.

Using that knowledge, it is possible to determine the additional total profit that would result for a company if the repurchase rate could be modified by changing the behaviour of customers. This knowledge can lead to the development of marketing programmes aimed at particular customer segments.

\section{INCREASING THE RETENTION RATE.}

All the factors in a lifetime value table can be manipulated by marketing programmes: the average order size, the number of orders per year and the retention rate. To see the way this works, let us focus on only one factor, the retention rate, and see what would happen if WardChem could increase that rate by 5 per cent - an achievable goal for most companies. WardChem could go about it by:

- setting up a relationship building team for their top customers

— providing a much higher level of customer service

- setting up a super customised web page for each customer

- putting thousands of pages of technical information about their chemicals on the Web for their customers (only) to use.

It is assumed that the cost of all of these additional relationship-building activities cost them about $\$ 110$ per customer per year, or about $\$ 5 \mathrm{~m}$. There could be two results: the retention rate might go up by 5 per cent and the number of orders might go up by one half of an order per year. Table 8 shows what could happen.

Lifetime value in the third year has gone up from $\$ 11,907$ to $\$ 13,362$. What does that mean for WardChem in terms of profits? It means extra profits of more than $\$ 65 \mathrm{~m}$ - after taking into account the extra $\$ 5 \mathrm{~m}$ per year spent on relationship building activities.

Lifetime value charts like these are used in calculating the value of a name. They are very powerful predictors of success in database marketing. 
Table 8: Revised lifetime value

\begin{tabular}{llll}
\hline & Year $\mathbf{1}$ & Year 2 & Year 3 \\
\hline Retention rate & $75 \%$ & $80 \%$ & $85 \%$ \\
Retained customers & 45,000 & 33,750 & 27,000 \\
Average order & $\$ 2,500$ & $\$ 2,700$ & $\$ 2,900$ \\
Orders per year & 8.5 & 9.5 & 10.5 \\
Total revenue & $\$ 956,250,000$ & $\$ 865,687,500$ & $\$ 822,150,000$ \\
Cost percent & $75 \%$ & $71 \%$ & $69 \%$ \\
Variable costs & $\$ 717,187,500$ & $\$ 614,638,125$ & $\$ 567,283,500$ \\
Acquisition cost $(\$ 1,400)$ & $\$ 63,000,000$ & 0 & 0 \\
Retention costs $(\$ 200)$ & $\$ 9,000,000$ & $\$ 6,750,000$ & $\$ 5,400,000$ \\
Total costs & $\$ 789,187,500$ & $\$ 621,388,125$ & $\$ 572,683,500$ \\
& & & $\$ 244,299,375$ \\
Gross profit & $\$ 167,062,500$ & 1.09 & $\$ 249,466,500$ \\
Discount rate & 1.01 & $\$ 223,953,322$ & $\$ 212,564,425$ \\
Net present value profit & $\$ 164,767,265$ & $\$ 388,720,586$ & $\$ 601,285,011$ \\
Cumulative NPV profit & $\$ 164,767,265$ & $\$ 8,638$ & $\$ 13,362$ \\
Lifetime value & $\$ 3,661$ & & \\
\hline
\end{tabular}

Table 9: Gains through retention building activities

\begin{tabular}{llll}
\hline & Year $\mathbf{1}$ & Year 2 & Year 3 \\
\hline New LTV & $\$ 3,661$ & $\$ 8,638$ & $\$ 13,362$ \\
Old LTV & $\$ 3,462$ & $\$ 7,926$ & $\$ 11,907$ \\
Difference & $\$ 200$ & $\$ 712$ & $\$ 1,454$ \\
Times 45,000 customers & $\$ 8,987,305$ & $\$ 32,046,283$ & $\$ 65,451,072$ \\
\hline
\end{tabular}

\section{THE VALUE OF AN E-MAIL NAME}

A name and address with the matching e-mail and permission to use it can be a very valuable commodity - much more valuable than a simple name and address. There are many reasons why this is so:

- it is far cheaper to send e-mail communications than direct mail communications, so money is saved on each communication

- since e-mails are so cheap and so fast, it is possible to undertake many communications that simply could not be done at all with direct mail

- using e-mails, close relationships can be that built could not be done with direct mail or phone. As a result the e-mail will add to the retention rate of certain customers, which adds directly to their lifetime value

- e-mails can be used in viral marketing, ie customers can be encouraged to write to each other, passing the company's message to other people

- the speed of e-mails permits the company to send types of messages that could not be sent by any other medium. Airlines, for example, send weekly messages about the availability of unsold seats at rock bottom prices. These messages could not be sent by mail because of the time, or by phone because of the cost and the annoyance factor.

Putting all these factors together a start can be made on estimating the value of an e-mail name. The numbers in Table 10 are very important and lie at the heart of the relationship between modern database marketing and the Web. Each is discussed in turn. 
Table 10: Annual e-mail name value

\begin{tabular}{lll}
\hline Total annual value & Direct mail & e-mail value \\
\hline Regular promotion & $\$ 0.80$ & $\$ 1.28$ \\
Low cost item promotion & NA & $\$ 0.32$ \\
Last minute special & NA & $\$ 2.48$ \\
Retention messages & $\$ 2.40$ & $\$ 3.68$ \\
Follow up messages & $\$ 1.20$ & $\$ 9.12$ \\
Viral marketing & NA & $\$ 0.24$ \\
Newsletter & $\$ 1.20$ & $\$ 2.24$ \\
Rental value & $\$ 0.42$ & $\$ 4.20$ \\
Total annual value & $\$ 6.02$ & $\$ 23.56$ \\
\hline
\end{tabular}

Table 11: Regular promotion profit per name

\begin{tabular}{lll}
\hline Regular promotion & Mail & e-mail \\
\hline Sent & 200,000 & 200,000 \\
Cost each & $\$ 0.50$ & $\$ 0.04$ \\
Promotion cost & $\$ 100,000$ & $\$ 8,000$ \\
Response rate & $3.0 \%$ & $1.0 \%$ \\
Responses & 6,000 & 2,000 \\
Profit per response & $\$ 20.00$ & $\$ 20.00$ \\
Profits & $\$ 120,000$ & $\$ 40,000$ \\
Net profits & $\$ 20,000$ & $\$ 32,000$ \\
Eight promotions per year & $\$ 160,000$ & $\$ 256,000$ \\
Annual profit per name & $\$ 0.80$ & $\$ 1.28$ \\
\hline
\end{tabular}

\section{REGULAR PROMOTIONS.}

Message for message, e-mail is cheaper to send. Victoria's Secret has used e-mail marketing for several years. It has more than $4.5 \mathrm{~m}$ customer e-mails on its database. It outsources its e-mail to Digital Impact. The e-mails are timed to coincide with Victoria's Secret catalogue distribution. This type of e-mail generates a purchase rate of about 6 per cent according to Shar Van Boskirk of Forrester Research.

Suppose regular promotions are sent four times per year to the customer base. The response rate might look as shown in Table 11.

As can be seen, the response rate to direct mail is higher than that to e-mail. This will normally be true, although not always. The high cost of direct mail in comparison swamps the improved response rate giving the profit per name of e-mail a 60 per cent lift.

At a rate of four promotions per year, the e-mails are worth $\$ 1.28$ per year or
$\$ 0.48$ more than a simple name and address.

\section{LOW COST ITEM PROMOTION}

There are many items that simply cannot be profitably promoted by direct mail. One example is the Universal Music promotion of musical CDs, which sell for about $\$ 20$ each. The profit to a company selling a $\$ 20$ item directly is probably in the order of $\$ 8.00$ per item. The promotion could work out as shown in Table 12.

Direct mail loses money so no one would attempt it. Each e-mail name earns, on the other hand, a healthy $\$ 0.32$ per year. This is found money that comes from having the e-mails.

\section{LAST MINUTE SPECIAL}

Only certain companies have last minute specials. These include airlines, trains, hotels, rental cars, cruise lines, live 
Table 12: Profit from low cost item promotion

\begin{tabular}{lll}
\hline Low cost item promotion & Mail & e-mail \\
\hline Sent & 200,000 & 200,000 \\
Cost each & $\$ 0.50$ & $\$ 0.04$ \\
Promotion cost & $\$ 100,000$ & $\$ 8,000$ \\
Response rate & $3.0 \%$ & $1.0 \%$ \\
Responses & 6,000 & 2,000 \\
Profit per response & $\$ 8.00$ & $\$ 8.00$ \\
Profits & $\$ 48,000$ & $\$ 16,000$ \\
Net profits & $-\$ 52,000$ & $\$ 8,000$ \\
Eight promotions per year & NA & $\$ 64,000$ \\
Annual profit per name & NA & $\$ 0.32$ \\
\hline
\end{tabular}

Table 13: Profit from a last minute special

\begin{tabular}{lll}
\hline Last minute special & Mail & e-mail \\
\hline Sent & NA & 200,000 \\
Cost each & NA & $\$ 0.04$ \\
Promotion cost & NA & $\$ 8,000$ \\
Response rate & NA & $0.5 \%$ \\
Responses & NA & 1,000 \\
Profit per response & NA & $\$ 70.00$ \\
Profits & NA & $\$ 70,000$ \\
Net profits & NA & $\$ 62.000$ \\
Profit per name & NA & $\$ 0.31$ \\
50 promotions per year & NA & $\$ 2.48$ \\
\hline
\end{tabular}

theatre, sporting events and concerts: any company that sells something that disappears if not used. It also applies to retail stores that are having a special sale that comes to an end in a very few days. These things cannot be sent by regular mail because it is too slow. Table 13 shows what the value looks like.

A last minute special is pure profit. The seats are going empty. It costs very little to let people sit in them. Even at a very low response rate, the profits are substantial, and the annual value of a name is considerable.

\section{RETENTION MESSAGES}

Every database marketer likes to think up retention messages. What are they? Birthday cards, anniversary cards, season's greetings, thank you messages, customer surveys, service reminders, quarterly savings summaries, etc. The value of these messages is not in the response, since none is requested or expected. The value is due to the fact that they keep customers from defecting by building profitable relationships with them. The profit comes from the increased retention rate and the consequent increased lifetime value.

To understand this, it is useful to set up a control group that does not get the retention messages. Then the lifetime value of this group is determined.

Table 14 represents customers of a women's dress chain that has several stores. It costs them $\$ 170$ to acquire women who make two visits to the store per year, spending an average of $\$ 160$ per visit. The store retains only 40 per cent of these women into the second year. Of those left, 50 per cent remain to the third year. The number of visits and spending per visit tend to grow among the loyalists still shopping at the 
Table 14: Women's dress chain customer LTV

\begin{tabular}{|c|c|c|c|}
\hline Control LTV & Year 1 & Year 2 & Year 3 \\
\hline Customers & 200,000 & 80,000 & 40,000 \\
\hline Retention rate & $40 \%$ & $50 \%$ & $60 \%$ \\
\hline Visits per year & 2 & 3 & 4 \\
\hline$\$$ per visit & $\$ 160$ & $\$ 200$ & $\$ 220$ \\
\hline Revenue & $\$ 64,000,000$ & $\$ 48,000,000$ & $\$ 35,200,000$ \\
\hline Cost percent & $60 \%$ & $58 \%$ & $56 \%$ \\
\hline Cost & $\$ 38,400,000$ & $\$ 27,840,000$ & $\$ 19,712,500$ \\
\hline Acquisition cost $(\$ 170)$ & $\$ 34,000,000$ & & \\
\hline Mail marketing messages @ $\$ 0.50$ & 6 & 6 & 6 \\
\hline Marketing costs & $\$ 600,000$ & $\$ 600,000$ & $\$ 600,000$ \\
\hline Total cost & $\$ 73,000,000$ & $\$ 28,440,000$ & $\$ 20,312,000$ \\
\hline Profit & $-\$ 9,000,000$ & $\$ 19,560,000$ & $\$ 14,888,000$ \\
\hline Discount rate & 1.00 & 1.07 & 1.15 \\
\hline Net present value profit & $-\$ 9,000,000$ & $\$ 18,246,269$ & $\$ 12,955,280$ \\
\hline Cumulative NPV profit & $-\$ 9,000,000$ & $\$ 9,246,269$ & $\$ 22,201,548$ \\
\hline Lifetime value & $-\$ 45.00$ & $\$ 46.23$ & $\$ 111.01$ \\
\hline
\end{tabular}

store. The store spends $\$ 4$ per year on direct mail marketing messages including seasonal specials. They lose money on women acquired in the first year, but overall earn a good profit from those who remain so that the lifetime value of a newly acquired customer after three years is $\$ 111$. The store is doing well.

The next step is to determine the effect of additional e-mail retention messages on a similar group of women, the test group. These women get 36 personalised e-mail retention messages per year from the store in addition to the regular direct mail. These messages cost $\$ 0.04$ per message. They have the effect of increasing the retention rate by 5 per cent, the number of visits per year by 0.2 visits more and the spending rate per visit by $\$ 5.00$. The results are shown in Table 15.

As can be seen, these retention messages have a dramatic effect on the women's behaviour. Note that this effect could not have been obtained by simply increasing the direct mail which was costing about $\$ 0.50$ per message. Had that been tried, 36 messages per year would have cost $\$ 18$ per customer or $\$ 3.6 \mathrm{~m}$ per year, which would have seriously eaten into profits. In addition, many of these e-mail messages were quite timely, and could not have been sent at all by direct mail.

The effect of the e-mail can be seen in the comparison in Table 16. The gain to the store is $\$ 12 \mathrm{~m}$ pure profit in the third year.

Next the retention messages can be evaluated. As can be seen in Table 17, increases in retention and lifetime value are much more difficult to measure than other direct marketing factors. There have to be control groups that do not get the retention messages and then it can be seen, after a year or so, whether there is a difference in the retention rate and the lifetime value. The only difference between e-mail and direct mail here is that direct mail is probably more effective in building retention than e-mail. A thank you letter printed and mailed means more than a thank you e-mail. The same might be true of birthday cards and other retention messages. On the face of it, however, it is a lot easier to get management to release $\$ 8,000$ for e-mail birthday cards than $\$ 100,000$ for direct mail ones. The probability is that the e-mails will be 
Table 15: Improved LTV through retention messages

\begin{tabular}{llll}
\hline Test LTV & Year 1 & Year 2 & Year 3 \\
\hline Customers & 200,000 & 88,000 & 47,520 \\
Retention rate & $44 \%$ & $54 \%$ & $64 \%$ \\
Visits per year & 2.2 & 3.2 & 4.2 \\
$\begin{array}{l}\text { \$ per visit } \\
\text { Revenue }\end{array}$ & $\$ 165$ & $\$ 210$ & $\$ 240$ \\
Cost percent & $\$ 72,600,000$ & $\$ 59,136,000$ & $\$ 47,900,160$ \\
Cost & $60 \%$ & $58 \%$ & $56 \%$ \\
Acquisition cost $(\$ 170)$ & $\$ 43,560,000$ & $\$ 34,298,880$ & $\$ 26,824,090$ \\
Direct mail marketing @ \$0.50 & $\$ 34,000,000$ & 6 & 6 \\
Marketing costs & $\$ 600,000$ & $\$ 600,000$ & $\$ 600,000$ \\
e-mail messages @ \$0.04 & 36 & 36 & 36 \\
e-mail total & $\$ 288,000$ & $\$ 126,720$ & $\$ 68,429$ \\
Total cost & $\$ 78,448,000$ & $\$ 35,025,600$ & $\$ 27,492,518$ \\
& & & $\$ 20,407,642$ \\
Profit & $\$ 5,848,000$ & 1.07 & 1.15 \\
Discount rate & 1.00 & $\$ 22,491,045$ & $\$ 17,758,376$ \\
Net present value profit & $-\$ 5,848,000$ & $\$ 16,643,045$ & $\$ 34,401,421$ \\
Cumulative NPV profit & $-\$ 5,848,000$ & $\$ 83.22$ & $\$ 172.01$ \\
Lifetime value & $-\$ 29.24$ & & \\
\hline
\end{tabular}

Table 16: Gains through retention

\begin{tabular}{llll}
\hline Gain from e-mail & Year $\mathbf{1}$ & Year 2 & Year 3 \\
\hline Control & $-\$ 45.00$ & $\$ 46.23$ & $\$ 111.01$ \\
Test & $-\$ 29.24$ & $\$ 83.22$ & $\$ 172.01$ \\
Gain from use of e-mail & $\$ 15.76$ & $\$ 36.98$ & $\$ 61.00$ \\
With 200,000 customers & $\$ 3,152,000$ & $\$ 7,396,776$ & $\$ 12,199,873$ \\
\hline
\end{tabular}

Table 17: Name value from retention messages

\begin{tabular}{lll}
\hline Retention messages & Mail & e-mail \\
\hline Sent & 200,000 & 200,000 \\
Cost each & $\$ 0.50$ & $\$ 0.04$ \\
Promotion cost & $\$ 100,000$ & $\$ 8,000$ \\
Increased retention & $0.080 \%$ & $0.050 \%$ \\
Current LTV & $\$ 111.01$ & $\$ 111.01$ \\
Increased LTV & $\$ 0.80$ & $\$ 0.50$ \\
Total LTV increase & $\$ 160,000$ & $\$ 100,000$ \\
Net profits & $\$ 60,000$ & $\$ 92,000$ \\
Eight messages per year & $\$ 480,000$ & $\$ 736,000$ \\
Annual name value & $\$ 2.40$ & $\$ 3.68$ \\
\hline
\end{tabular}

much more widely used as people see the value in them. So the e-mail will probably be the clear winner in retention messages.

\section{FOLLOW UP MESSAGES}

Here is an area where e-mail wins in a walk. When people order something, the order is followed up with an e-mail confirmation (or a mailed confirmation). When the product is about to be shipped, the notice with the tracking number can be e-mailed (it is too late to do this by mail). When the product arrives, an e-mail survey is sent: did it arrive alright, and was it to the customer's liking? Here, 
Table 18: Name value from follow up

\begin{tabular}{lll}
\hline Follow up messages & Mail & e-mail \\
\hline Sent & 200,000 & 200,000 \\
Cost each & $\$ 0.50$ & $\$ 0.04$ \\
Promotion cost & $\$ 100,000$ & $\$ 8,000$ \\
Increased retention & $0.01 \%$ & $0.01 \%$ \\
Current LTV & $\$ 111.01$ & $\$ 111.01$ \\
Increased LTV & $\$ 0.80$ & $\$ 0.80$ \\
Total LTV increase & $\$ 160,000$ & $\$ 160,000$ \\
Net profit & $\$ 60,000$ & $\$ 152,000$ \\
$4 / 12$ per year & $\$ 240,000$ & $\$ 1,824,000$ \\
Annual name value & $\$ 1.20$ & $\$ 9.12$ \\
\hline
\end{tabular}

again, the e-mail wins. The value is measured in customer retention and increased lifetime value.

It may be that the company can send only four direct mail follow up messages per year, but it could send 12 e-mails or more depending on transactions. The effect on retention and LTV from each message would be the same to the customer.

Because of the cost of direct mail follow up messages, very few companies send them. A better comparison than e-mail versus direct mail for follow up messages would be to test e-mail versus no follow up at all. The boost in retention can be measured over a period of a year, and can be quite substantial.

\section{VIRAL MARKETING}

Viral marketing is an interesting concept that only works in certain product situations. Some customers can be so excited about some product that they will write to their friends about it. The kinds of situations that work for viral marketing are:

\footnotetext{
- concerts

- firearms

- automobiles

- travel destinations

- books
}

— political candidates
— health foods.

Figure 1 illustrates how viral marketing works. It works by sending an e-mail to customers inviting them to invite other customers by entering their names on a micro-site. This site, connected to the company database, records the names and suggests messages to be sent to the names. When the customer clicks OK, the messages are sent and if they 'click here' they see a micro-site inviting them to accept the offer, thus helping the customer and themselves.

In this example, one e-mail results in the capture of more names and ultimately thousands of other e-mails all promoting the product. Viral marketing is unique to e-mail marketing. It cannot effectively be done by direct mail or phone.

Viral marketing can be used for both very inexpensive items or expensive ones. The cost per sale of $\$ 16.67$ shown in Table 19 assumes that the viral messages sent by customers to their friends will have a higher response rate than messages sent to prospects or to customers in general. Viral marketing can be very powerful if artfully used.

\section{NEWSLETTERS}

E-mail newsletters have become very popular. They save a lot of money. 


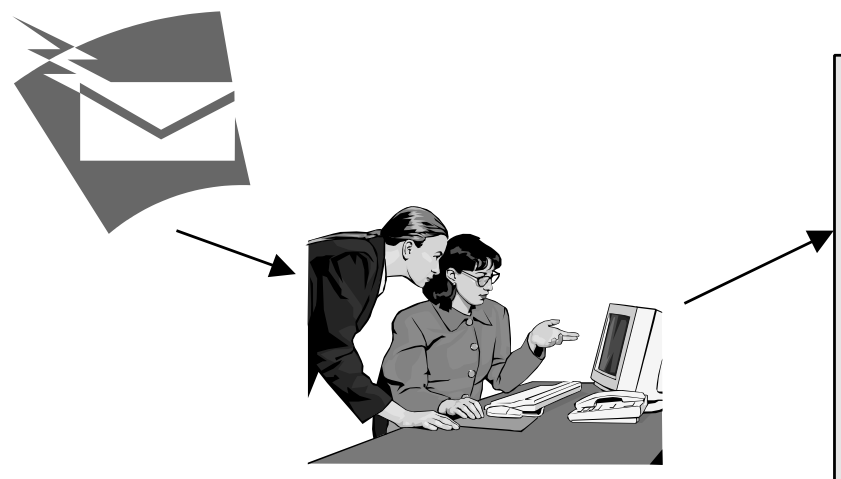

Viral e-mail results in more e-mails and data capture

Dear Helena: Rick and I are going to Hawaii on August $7^{\text {th }}$. We thought it would be great if you could come with Us. We are staying at the Maui Surfside which is a great deal. To find out about it Click here! Hope you can

Figure 1: Viral marketing
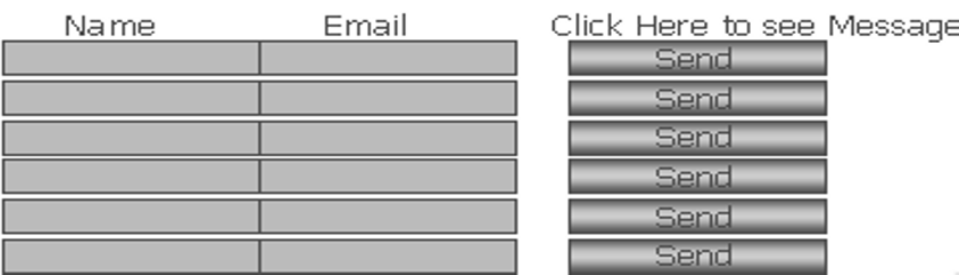

Figure 2: Viral e-mail despatch

They often get a good response rate. It should be easy for recipients to discontinue them with one click. It is not as easy for the recipients of direct mail newsletters. Newsletters result in increased retention, sales and loyalty. They are usually worth the effort if the company can put something into them that its customers want to read.

\section{NAME RENTALS}

Of course, a file of opt-in names of customers who have agreed that they will accept promotions from a company's business partners, has another valuable use. Since the names are being used more effectively, it is safe to assume that others will be doing the same. E-mails have caught on. Billions 
Table 19: Name value from viral marketing

\begin{tabular}{lll}
\hline Viral marketing & Mail & e-mail \\
\hline Sent & NA & 200,000 \\
Cost each & NA & $\$ 0.04$ \\
Promotion cost & NA & $\$ 8,000$ \\
Response rate & NA & $2.0 \%$ \\
Response & NA & 4,000 \\
e-mails captured & NA & 1.5 \\
e-mails sent & NA & 6,000 \\
Success rate & NA & $8 \%$ \\
Sales @ \$100 & NA & 480 \\
Sales & NA & $\$ 48,000$ \\
Cost per sale & NA & $\$ 16.67$ \\
Value of a name & NA & $\$ 0.24$ \\
\hline
\end{tabular}

Table 20: Name value from newsletters

\begin{tabular}{lll}
\hline Newsletter & Mail & e-mail \\
\hline Sent & 200,000 & 200,000 \\
Cost each & $\$ 0.50$ & $\$ 0.04$ \\
Promotion cost & $\$ 100,000$ & $\$ 8,000$ \\
Response rate & $2.00 \%$ & $1.50 \%$ \\
Responses & 4,000 & 3,000 \\
Average sale & $\$ 100.00$ & $\$ 100.00$ \\
Profit per sale & $\$ 40.000$ & $\$ 40.000$ \\
Profit from newsletter & $\$ 160,000$ & $\$ 120,000$ \\
Net profit & $\$ 60,000$ & $\$ 112,000$ \\
12 per year & $\$ 240,000$ & $\$ 448,000$ \\
Annual profit per name & $\$ 1.20$ & $\$ 2.24$ \\
\hline
\end{tabular}

of commercial e-mail messages are being sent every week. There is a massive market for opt-in names. If the direct mail names can be rented eight times a year, they can certainly be rented ten times that, ie 80 times per year. The price per thousand of e-mail names varies widely. Taking a conservative estimate of $\$ 70$ per thousand for both direct mail and e-mail names with permission to use them for partner messages, Table 21 shows what the renter can expect to receive during a year for each name.

\section{CONCLUSION}

The value of a name is summarised again in Table 22. Of course, not every company can use every one of these marketing methods, but a company can certainly use at least half of them. It can be said with some confidence that e-mail names, with permission, are worth at least $\$ 15-\$ 20$ each to any company. To the author's knowledge, no company has sat down and done this analysis and knows, with any kind of precision, what e-mails are worth to them. What does that number dictate in terms of marketing strategy? - That e-mails must be collected and permission to use them obtained.

How can a company do that? By every means at its disposal:

- telemarketers must be compensated for capturing these names

- every form should be revised to include a space for the e-mails. It is no use waiting for the forms to run out, they should be junked and new ones printed - contests can be run in which to enter a customer goes on the Web to a 
Table 21: Value of name rental

\begin{tabular}{lll}
\hline Rental value & Mail & e-mail \\
\hline Rental per year & 8 & 80 \\
CPM & $\$ 70.00$ & $\$ 70.00$ \\
Revenue & $\$ 0.56$ & $\$ 5.60$ \\
Commissions & $\$ 0.14$ & $\$ 1.40$ \\
Net revenue & $\$ 0.42$ & $\$ 4.20$ \\
\hline
\end{tabular}

Table 22: Total name value

\begin{tabular}{lll}
\hline Total annual value & Direct mail & e-mail value \\
\hline Regular promotion & $\$ 0.80$ & $\$ 1.28$ \\
Low cost item promotion & NA & $\$ 0.32$ \\
Last minute special & NA & $\$ 2.48$ \\
Retention messages & $\$ 2.40$ & $\$ 3.68$ \\
Follow up messages & $\$ 1.20$ & $\$ 9.12$ \\
Viral marketing & NA & $\$ 0.24$ \\
Newsletter & $\$ 1.20$ & $\$ 2.24$ \\
Rental value & $\$ 0.42$ & $\$ 4.20$ \\
Total annual value & $\$ 6.02$ & $\$ 23.56$ \\
\hline
\end{tabular}

micro-site and enters their e-mail with permission to use it

- creativity is essential, the company gains $\$ 10$ per year for every e-mail captured

- Lenscrafters gives $\$ 10$ for each e-mail name provided by customers.
This is a new millennium and the rules of the game have changed. Like the invention of catalogues, direct mail, radio or television, this new phenomenon, e-mail, has fundamentally changed the nature of marketing and marketers must change with it. 